\title{
Spirit baptism and the doctrine of initial evidence in African Pentecostal Christianity: A critical analysis
}

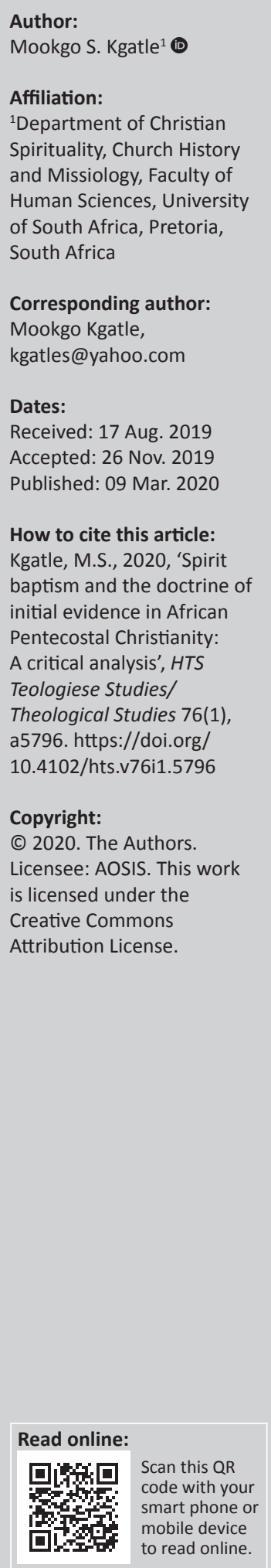

Pentecostalism is known for the belief in Spirit baptism that is accompanied by the doctrine of initial evidence, that is, speaking in tongues. The practice of the doctrine of initial evidence has become a unique feature of Pentecostalism for many years since its beginning. Similarly, Spirit baptism and the doctrine of initial evidence are practised in African Pentecostal Christianity, especially in classical Pentecostal churches and charismatic movements. However, there are challenges with this doctrine: speaking in tongues is perceived as the only evidence, and there is an emphasis on gifts than fruit of the Holy Spirit and a great emphasis on public spiritual experiences than personal encounters with God. In re-imagining the doctrine of initial evidence in African Pentecostal Christianity, speaking in tongues should not be emphasised or practised as the only evidence of Spirit baptism because there are other evidences that demonstrate the baptism in the Holy Spirit. The emphasis should be on prayer than the speaking of tongues. In addition, priority should be given to the fruit of the Spirit and on a personal encounter with God. Finally, speaking in tongues should be accompanied by interpretation in a public service because the public cannot understand the language.

Keywords: speaking in tongues; Spirit baptism; African Pentecostal Christianity; Holy Spirit; initial evidence.

\section{Introduction}

The baptism in the Holy Spirit with the initial evidence of speaking in tongues in the New Testament is a common subject, especially in the book of Mark, Luke-Acts and 1 Corinthians. Cartledge (2000) states that:

There are thirty-five references to what is commonly called 'speaking in tongues' in the New Testament. There are twenty-eight references in 1 Corinthians, of which twenty-three appear in chapter 14 . The remainder (seven) appear in the Gospel of Mark and the Acts of the Apostles. (p. 135)

Speaking in tongues is equally a common practice among Pentecostal Christians. The practice has been embraced by classical Pentecostal churches and charismatic movements. The practice is not that common in African Initiated Churches (AIC). The main argument in this article is that as much as speaking in tongues is the initial evidence of Spirit baptism, it is not the only evidence. There are other evidences of Spirit baptism like prayer, witnessing, worship, teaching and guidance that are mentioned in scriptures and show that a believer has been baptised with the Holy Spirit. The problem with practicing tongues as the only evidence is that people will end up putting an emphasis on gifts than fruit of the Holy Spirit.

Another problem is that believer ends up focussing on the outward and public spiritual experiences instead of a genuine relationship with God. Consequently, even those who have not received the gift of speaking in tongues end up faking them. A story is told of a Tsonga man who faked tongues among the Zulus. The man took an advantage of their ignorance of Tsonga and he went on to say 'va kadziya va jika' repeatedly; they thought he was praying in other tongues, but he was simply saying 'they climb and get off' repeatedly.

Agrippa Khathide, an ordained minister of the Apostolic Faith Mission (AFM) of South Africa, counsellor, motivational speaker and head of the Missiology Department at the Auckland Park Theological Seminary, used to joke with his students at the seminary that they are not praying in tongues but are mocking his last name by saying 'ikhanda la khathide' repeatedly, literally meaning 'the head of khathide'. 
In a way of correcting this charlatan practices, this article reimagines the practice of speaking in tongues and doctrine of initial evidence in African Pentecostal Christianity. In this article, one proposes that tongues should not be perceived as the only evidence and emphasis should be placed on prayer and fruit of the Holy Spirit. The believers should endear for a personal relationship with God than public expressions. Believers should also endear for interpretation of tongues especially in a public service.

\section{Spirit baptism and doctrine of initial evidence defined}

The essence of Pentecostalism is the baptism of the Holy Spirit and the gifts of the Spirit, especially the gift of speaking in tongues as the initial evidence of baptism in the Holy Spirit. The baptism of believers in the Holy Spirit is witnessed by the initial physical sign of speaking with other tongues as the Spirit of God gives them utterance. In Acts 19:6, when Paul placed his hands on the Ephesian elders, the Holy Spirit came on them, and they spoke in tongues while others prophesied. All the forefathers of a Pentecostal movement preached this doctrine of initial evidence. Charles Parham, for example, formulated the theological tenet that supported speaking in tongues as the initial evidence of Holy Spirit baptism. William Seymour caught that message and implemented it in Los Angeles, Azusa Street, and from there it spread to other regions of the world (Baer 2001:754). One of the regions where it spread is South Africa because of the influence of John G Lake who also supported the doctrine of speaking in tongues as the initial evidence of Spirit baptism.

Consequently, the doctrine of speaking tongues became the practice in the AFM of South Africa, a church started by John G Lake (Hwata 2005:87).

Speaking in tongues in this instance is the same in essence as the gift of tongues (1 Cor 12:4-28), but different in purpose and use. According to Hollenweger (1986:406), 'the doctrine of initial evidence: each believer is expected to undergo, subsequent to and different from conversion, a second religious crisis experience whose outward sign is speaking in tongues'. In most cases, when a believer is not speaking in tongues, he is perceived as not having received the baptism of the Holy Spirit. This is because among Pentecostals, speaking in tongues is perceived as the most evidence that one has been baptised with the Holy Spirit. Therefore, a better term to describe the connection between speaking in tongues and Spirit baptism is concomitant. Stephenson (2009) says:

\footnotetext{
Speaking in tongues is not just one of the concomitants of being Spirit-filled, but is the most natural and regular concomitant of Spirit-filling involving an invasive or irruptive manifestation of the Spirit in which one's relationship to Jesus Christ is radically and significantly altered. When one experiences the coming of the Spirit in such a manner, the most natural and spontaneous response is speaking in tongues. (p. 85)
}

However, the premise of this article is that tongues should not be perceived as the only evidence. The article argues against the sole evidence of speaking in tongues because there are other evidences. In addition, it must be noted according to Yong (2007) that:

$[W]$ hile earlier Pentecostals were interested in apologetic articulations of the doctrine of speaking in tongues as the initial physical evidence of the filling or baptism of the Holy Spirit (a dogma for many Pentecostal denominations derived from Azusa Street, such as the Assemblies of God), the ecumenical tradition of Pentecostalism has begun to understand tongues as a sign of the multilinguistic and multicultural kingdom of God. Hence, the new generation of Pentecostal theologians has been more concerned with developing a theology of speaking in tongues and charismata set within a broader ecumenical, pneumatological, and Trinitarian framework. (p. 248)

It is therefore the goal of this article to reimagine the Spirit baptism and the doctrine of initial evidence, that is, speaking in tongues. This study will assist modern-day Pentecostals and non-Pentecostals to a certain extent to have a better understanding with regard to speaking in tongues.

\section{The doctrine of initial evidence in African Pentecostal Christianity}

Among African Pentecostals, speaking in tongues is usually regarded according to Anderson (1991):

$[A] \mathrm{s}$ the initial evidence of receiving the Holy Spirit. The phenomenon is of central significance to faith and practice. It is also the phenomenon which largely distinguishes 'charismatics' from other Christians in the 'historic' Western churches. (p. 47)

African Pentecostals are known in the words of Musoni (2014):

For the baptism of the Holy Spirit with the initial evidence of speaking in tongues. Great emphasis is placed on the experiential side of the Christian life among Pentecostals. For African Pentecostal Christians there are two important Spiritual experiences firstly, it is the New Birth; and secondly it is the baptism of the Holy Spirit with speaking in tongues as initial evidence. (p. 135)

Musoni (2014) continues to narrate a story of a certain Pastor in the rural Bindura:

Who lined up his church leaders asking them to speak in tongues one after the other testing the vitality of the Holy Spirit within them. Those who would fail to speak in tongues were demoted from Church hierarchy. This narration becomes a sacred belief and practice of African Pentecostal Churches particularly. Members from Apostolic Faith Mission of Zimbabwe for example maintained the same position that anyone who does not speak in tongues cannot be appointed into leadership. (p. 136)

In the AFM of South Africa, a Pentecostal church, according to their constitution (2018):

$[I] \mathrm{t}$ is believed that the baptism in the Holy Spirit with the initial evidence of speaking in tongues is promised to all believers. The gifts and fruit of the Spirit will be manifested in the life of a Christian, and a Christian should be a disciple of Jesus Christ living a consecrated and holy life. (p. 1) 
In the African Pentecostal Christianity, the uniform speaking in tongues is a sign of the new important covenant of unity and love of Christ on every Christian believer. African Pentecostals, especially classic Pentecostalism, take their beliefs and teachings as rooted in the book of Acts and 1 Corinthians, presenting a challenge on the contemporary status of certain biblical texts (Machingura 2011:17). In African Pentecostal churches, speaking in tongues is encouraged in every believer as a sign of Spirit baptism and the fruits of Spirit-filled life. In this view, African Pentecostal churches understand speaking in tongues as a means of going beyond the gifts, as illustrated in I Corinthians 14 . They embrace the Acts 2:4 experience and the Acts 19:6 reference to Spirit baptism. As such according to Chebanne, the phenomenon is core to the 'Spirit-filled' life of every Christian. Prophecy is often done, although speaking in tongues expressions and interpretations may be done by the utterer or from the listeners (Chebanne 2006:170).

African Pentecostals believe that the Spirit's active presence becomes most evident through believers' reception and experience of Spirit baptism. They believe that the promise of the Holy Spirit is for all believers and to their children, and to all that are afar off, even as many as the Lord our God shall call as indicated in Acts 2:39. They equally believe that this promise comes with a total package that includes speaking in tongues as the Spirit gives utterances. It is believed that generally such experience must be accompanied by speaking in tongues (Quayesi-Amakye 2016:76). In addition, African Pentecostal churches practise speaking in tongues as the gift of the Holy Spirit. They distinguish between two functions of speaking in tongues, namely, speaking in tongues as initial evidence of Spirit baptism and speaking in tongues as one of the gifts of the Holy Spirit. To the African Pentecostal churches, the initial evidence of speaking in tongues is not part of the gifts of the Spirit.

The practice of Spirit baptism and the doctrine of initial evidence should also be discussed in the context of three waves of Pentecostalism in Africa, that is, classical, NeoPentecostal and African Independent Churches. All these churches according to Mashau (2013):

$[C]$ an be categorised under the umbrella of the Pentecostal movement in Africa because they all emphasise the working of the Holy Spirit. However, it should be noted at this stage that they vary from one another in terms of their modus operandi. Classical Pentecostals are firm on 'speaking in tongues' as initial evidence of baptism with the Holy Spirit. The new Pentecostal churches on the other hand emphasise the power and the supernatural gifts of the Holy Spirit in the church, and their leaders replicate more of what American tele-evangelists do. The last category, mostly the AICs, which are known to be Pentecostals with some degree of qualification, commonly use objects like holy water, ropes and articles in their healing practices. This element is not common in the first two categories of the Pentecostal movement mentioned above. (p. 14)

Otherwise, there is also the last category that is outside of the other three waves of Pentecostalism in Africa, that is, prophetic movements that gave a combination of all three waves of Pentecostalism with an addition of prophecy in their spiritual menu.

\section{The challenges with the doctrine of initial evidence}

The first challenge with the doctrine of initial evidence is that speaking in tongues is perceived as the only evidence, while the scriptures are very clear and attesting to other evidences of the baptism in the Holy Spirit. Although it is not a standing or pronouncement of many Pentecostal churches, many believers still perceive tongues as the only evidence. According to Musoni (2014:137), 'critics of the initial evidence doctrine argue that it is illicit hermeneutics to base a doctrine on historical narrative'. It is true that speaking in tongues should not be the only evidence of Spirit baptism, but an argument against it cannot be based on historical narrative. There are many scriptures that support a continuation of the infilling of the Holy Spirit together with the evidence of speaking in tongues. Thus, speaking in tongues is not only a historical event but also a continual one. One such a scripture is Acts 2:39 that illustrates very well that the promise of Spirit baptism is for generations to come. The argument against the doctrine of initial evidence in this article is based on the premise that speaking in tongues is not a sole evidence but one of the evidences.

Moreover, according to Hollenweger (1986:406) 'after the experience of the baptism of the Spirit not all believers will be expected to exercise the gift of speaking in tongues'. Hollenweger continues:

Within and without Pentecostalism there is criticism of this doctrine and practice. Important Pentecostal churches (for example, in Chile or certain countries in Europe) disagree with the doctrine of 'the initial physical sign' and believe that the baptism of the Holy Spirit is not always accompanied by this sign. In fact in many Pentecostal churches a great proportion of the members (and sometimes even some of the pastors) have never spoken in tongues. (p. 406)

While 'initial evidence' is to be affirmed to the extent that it is based on the insightful discernment of a close relationship between speaking in tongues and baptism in the Holy Spirit, according to Stephenson (2009):

[I]ts emphasis on speaking in tongues as 'proof' of fullness of the Spirit neither exhausts the theological significance of their relationship nor gives accurate account of how speaking in tongues actually functions for Pentecostals, namely, as a means of participating in God's self-disclosure through a medium stemming from the Kairos event of Pentecost. (p. 109)

This moves us to a second challenge, that is, an emphasis on gifts than fruit of the Holy Spirit. The Bible provides not emphasis on tongues as a gift but on character formation that exhibits the fruit of the Spirit, especially love (Gl 5:22-23; 1 Cor 13:1ff.; Rm 5:5). Otherwise according to Musoni (2014):

[I]f speaking in tongues is evidence that one has a unique infilling of the Holy Spirit, we would expect people who speak in tongues 
to generally manifest more of the fruits of the Spirit than others. (p. 137)

Practically, it is not so. Most people do speak in tongues, but do not demonstrate the fruit of the Spirit in their character. The researcher has observed people who speak in tongues, but cannot even quote a single scriptural text. This is caused by a belief that speaking in tongues is all what a believer needs to demonstrate their relationship with the Holy Spirit. While it is true that speaking in tongues shows that one has received the Holy Spirit, there is a need to acknowledge other proofs of Spirit baptism like the fruit of the Spirit.

The third challenge related to the second challenge discussed in this article is a great emphasis on public spiritual experiences than personal encounters with God. Those who speak in tongues in Pentecostalism seem to be good in doing so before the public which sometimes have negative connotations because the public cannot understand what they are saying. In addition, when the doctrine of initial evidence is overemphasised, it ends up producing believers who speak in tongues, but do not know God personally. The gift of tongues without the love of God is just an empty noise that one makes without sense. Tongues even if they can be of angels or of people without a love relationship with God, they are as good as nothing (1 Cor 13:1). The challenge for Pentecostal Christianity is to combine the gift of tongues with closer relationship with God through his love. The challenge is for believers to pray in tongues and love other people of God.

\section{Re-imagining the doctrine of initial evidence \\ Speaking in tongues is not the only evidence of Spirit baptism}

Speaking in tongues is not the only evidence of Spirit baptism. There is a need to make a distinction between the initial evidence and the only evidence; if something came first, it does not make it the only one. This might be the confusion among African Pentecostals to confuse the initial evidence as the only evidence. On the contrary, the scriptures attest to other evidences in the Bible. Mark expresses speaking in tongues as one of the signs that will follow those who believe, but Mark did not say that speaking in tongues is the only sign.

Mark 16:16-17 mentions other signs like casting out demons, taking up serpents, drinking deadly things without hurt and the laying on of hands on the sick for healing. The same way in Luke-Acts, for example, Acts 1:8, shows that believers receive power and are able to be witnesses after receiving the Holy Spirit. In this way, power and witnessing become evidences of Spirit baptism. Acts 2:4 speaks of the believer's speaking in tongues as the Spirit gave them utterance, but not as the only evidence of Spirit baptism. The challenge is that those who were baptised in the Holy Spirit immediately spoke in other tongues, but there is a need to clarify that other signs followed thereafter.
Elsewhere in Romans 8:26, the Spirit helps the believer who has received Spirit baptism on their weakness and the Spirit is able to intercede on behalf of the believer. This kind of help in intercession comes after the baptism of the Holy Spirit which makes intercession another sign of Spirit baptism. In Ephesians 5:18-20, Paul says to the Ephesians that they should not be drunk with wine wherein is excess, but be filled with the Spirit because they will be able to sing psalms and other spiritual songs. Singing psalms and other spiritual songs can happen anytime, but when one sings them in the spirit, they become a sign of Spirit baptism. In John 14:26, the Spirit is the one that teaches believers all things that Christ has taught his disciples. When the Spirit comes according to John 16:13, he is able to guide believers in all things. Thus, in the scriptures quoted above, we learn of other evidences of Spirit baptism like power, witnessing, intercession, prayer, teaching, worship and guidance. In all these instances, the believers could not do such acts without the baptism of the Holy Spirit. We cannot choose to emphasise the speaking in tongues as the only evidence.

It should be reiterated that speaking in tongues is not the only sign of Spirit baptism. It can be recognised as the important evidence in Pentecostalism, but it should not be taken as the outright evidence. The correct practice of the baptism of the Holy Spirit will therefore recognise other evidences and not single out one as the only one. It is therefore of paramount importance to take into cognisance what the Holy Spirit does in a believer post their baptism in the Holy Spirit. This calls for the recognition of other gifts and features of the Holy Spirit that a believer could not do prior their baptism in the Holy Spirit (Hollenweger 1986:406). It is important to note therefore that even the founders of Pentecostalism like Charles Parham desired that their audience will all speak in tongues, but in reality only few of those who received their message could speak in other tongues. This means that there are many believers within African Pentecostal Christianity who are baptised by the spirit, but they cannot speak in other tongues. Some of these believers are portraying other fruit and demonstrate other gifts of the Holy Spirit. Therefore, people should not be judged on the basis of not speaking in other tongues (see Musoni 2014:135).

The doctrine of the initial evidence requires a careful approach because while believers speak in other tongues as the sign that they have received the Holy Spirit, not all people who speak in tongues are actually baptised in the Holy Spirit. Some people are very good in coping others and can act as if they are baptised in the Holy Spirit while they are not. The other truth is that not all believers who are baptised in the Holy Spirit will speak in tongues because some believers are just not interested in the gift and they reject it as a consequence. Therefore, it will be wrong to judge them as those who are not baptised in the Holy Spirit. The challenge is to ascertain that those who speak in tongues in the church have indeed received the Holy Spirit.

This poses danger in the church and its liturgy because many will fake their tongues as if they have received them from the 
Holy Spirit and it will be difficult to isolate them. The remedy is to allow people to express their gifts without forcing them to speak in tongues, and this will ensure that people are liberated from just seeking something they are not gifted in and excel in their own gifts (see Hwata 2005:89).

\section{Speaking in tongues should serve as prayer}

Tongues act as prayer than spiritual gimmicks. Therefore, when a believer receives this gift they should not play with it in church or even in their own private prayer, but should use it to enhance their prayer time. The gift of tongues is essentially a gift of prayer, especially of praise and love. In this kind of prayer according to Ford (1971:16), 'usually the mind is not active but the prayer is one of simple, loving regard - often accompanied by the experience of God's presence'. This means that a believer is more likely to benefit more when praying in tongues than when praying in their own language because in theirs they have to think and pray while in tongues, they just continue to pray. Cartledge (2000:147) adds that the inspired prayer and praise are related to revelations of God's secret purposes, now being revealed, i.e. mysteries. In this function its preferred use is private'. In most cases in the words of Shumway (1919):

$[I] \mathrm{t}$ takes the form of earnest and continued prayer, usually with fasting, watching, great concentration of thought, and withal a definite expectation that the 'Pentecost' will sooner or later come. (p. 42)

When in fasting, the believer can pray in other tongues and gain strength in their spirit person.

In the context of prayer, speaking in tongues takes over the emotions of the believer as the worshippers take revitalising songs in worship, the Spirit of God then takes over. The believers will then tap into the speaking of tongues as they are revived by the spirit of worship and live music in Pentecostal service. Therefore, tongues come as a result of a combination of both music and worship that inspires many to enter into the speaking of tongues. Thereafter, many believers are able to feel something different in that different atmosphere created by the worship and music team (Amanze \& Shanduka 2015:4). At the end, tongues have an ability to provide a source of strength to the life of a believer that results in commitment to their Christianity. The believers who received the gift of speaking in tongues attest to the fact that the gift enables them to enjoy their prayer life which was not the case before they spoke in tongues.

It is the gift of tongues that offer to many a zeal and a new way of walking with God in their lives. Thus, tongues in prayer serve as a renewal to those who have earnestly received the gift (Busenitz 2006:76).

Therefore, speaking in tongues should not be used for gimmicks, but for the purpose of worshipping God, thanksgiving and in praising God (Zerhusen 1997:144). When one speaks in tongues is not necessarily speaking to human beings, but in direct communication with God in prayer.
Hence, most of the time human beings cannot understand the language spoken unless it is interpreted to them. The gift of speaking in tongues is more beneficial to the individual praying than to the larger community of believers. The capability to speak in tongues should be seen as a tool that gives a believer access to praise God and enter the realm of revelations and other mysteries of God. Hence, the one speaking in tongues is having a direct communion and communication with God. At the end, the gift of speaking in tongues is able to release various blessings and other benefits to a specific believer and the one praying in tongues. However, the believer should not brag to others that they can pray in tongues, but should use the gift to talk to God even when they do not understand the language. When the believer prays in tongues to show off, it loses its authenticity.

The Holy Spirit prays with believers and not instead of them and, as a result, the Holy Spirit participates with believers and assists them in prayer by turning their wordless groans into effective prayer. The Holy Spirit does not remove the believers' weaknesses or bear the burden wholly for them, but he comes to their aid and shares the load with them (Boddy \& Lioy 2016:2). Consequently, the believer feels strengthened and feels the power to carry on in his or her prayer even if his or her body or natural person is tired.

In this way, the Holy Spirit is considered an intercessor in the life of the believer. When a believer prays in tongues, they are entering an atmosphere where human effort is translated into the divine and it is no longer the person praying, but the Holy Spirit takes over. The Holy Spirit then takes the role in mediating between the needs of an individual and his or her God. The Holy Spirit reaches a level of talking to God on behalf of the believer as he knows the secrets of God. Therefore, by speaking in tongues, the believers are activating a reconciliation between themselves and their God. At the end, speaking in tongues brings healing and other emotional benefits in the life of a believer (Hwata 2005:87).

Yarnell (2006) argues against the point of connecting speaking in tongues with prayer by listing three points:

First, in the prayer of Romans 8, there is an explicit inability to utter words, while speaking in tongues explicitly concerns the utterance of words (cf. Acts 2:4). The only way to equate the phenomenon of Romans 8 with that of speaking in tongues is to engage in contradictory logic and say that 'not speaking' is 'speaking'. Second, through much of Romans 8, Paul discusses the Spirit's role in salvation, and Paul here expounds the prayer of faith which concerns personal regeneration by the Spirit. Third, if Paul had the gift of tongues in mind in his letter to the Romans, he would have included it in the gifts discussed in Romans 12:3-8. (p. 44)

However, Yarnell's argument is only based in Romans 8. In other scriptures like in 1 Corinthians 14, there is a connection between prayer and speaking tongues. Paul connects the prayer in tongues with the prayer in the Spirit and confirms that in such a prayer the mind is inactive. Therefore, the conclusion is that one has to pray in the spirit (thereafter referred to prayer in tongues) but also pray the prayer of understanding (1 Cor 14:14-19). 


\section{The emphasis should be on the fruit of the Holy Spirit}

The practice of speaking in tongues should not be emphasised than the fruit of the Holy Spirit. The believers who can speak in other tongues should also bear the fruit of the Holy Spirit in public life. The Bible itself does not emphasise the speaking in tongues over and above the fruit of the Holy Spirit which means that the character formation of the believer is important than their gifts (Gl 5:22-23; 1 Cor 13:1ff.; Rm 5:5). After all if a believer is able to live a holy life and display other fruit of the Holy Spirit, this is enough testimony to the world than the speaking of tongues. It is not always the case that the people who are able to speak in tongues will demonstrate a life full of the fruit of the spirit. If it was like that, majority of believers will indeed change the world as many of them can speak in tongues. Even believers in Corinthians were able to speak in tongues, but yet when it came to spiritual matters they were immature (1 Cor 3:1-4). This means that believers can speak in tongues, but be spiritual babies (see Musoni 2014:137), hence the call for believers to demonstrate the fruit than the gift.

\section{The priority should be on the personal relationship with God}

The priority should be on a personal relationship that the believers have with their God than just to speak in tongues in a church service. It is great when a believer speaks in tongue, and his or her relationship with God is equally intact; the life of that believer is fulfilled. However, one cannot speak in tongues while having a doubtful relationship with God, and that kind of tongues brings some form of emptiness in the life of believer.

Thus, speaking in tongues is a futile exercise if one is living a sinful life. After all, believers who have a personal relationship with God can speak to him at any given time even if they do not speak in other tongues. However, for someone who speaks in tongues but does not have a personal relationship with God, they will struggle to connect with him. The problem with prioritising tongues is that when people achieve tongues, they do not feel obligated to mend their relationship with God. After all anyone can speak in tongues, but is not everyone that can stand in a close relationship with God. Therefore, in Pentecostalism, there is a great need to set the priorities right without judging the practice of initial evidence.

\section{Tongues need interpretation in public service}

Lastly, there should be proper liturgy in African Pentecostal Christianity. As much as it is acceptable for African Pentecostals to practise speaking in tongues during a church service, such practice desires interpretation. The believer can speak in tongues in church, but they should not address the congregation in tongues unless they have an interpretation. Otherwise when in prayer or worship, anyone in their closet can speak in other tongues. If there is no interpretation, the public should be addressed in the language that they understand in their context. African Pentecostals should learn from Paul because although he has an ability to speak in many tongues, he chooses to use a common language in the church (1 Cor 14:18-19). The argument by Paul is that if everyone speaks in tongues, the people who cannot understand the language will conclude that church people are insane (1 Cor 14:23). The conclusion by Paul is that if people speak in tongues in the public, they must work with those who are gifted in interpretation. However, in the absence of those who can interpret, people should remain quiet in church. By this Paul does not discourage people to speak in tongues because he asserts that they can do so in talking to God (1 Cor 14:27-29).

\section{Conclusion}

African Pentecostals believe in the baptism of the Holy Spirit with the initial evidence of speaking in tongues. They have learnt this practice from the Bible in the book of Acts, Mark and Luke-Acts. The practice is also common in other regions, which makes the doctrine of speaking in tongues a global phenomenon. However, the evidence of speaking in tongues is not a sole evidence of Spirit baptism as currently practised by many Pentecostal churches. There are other evidences that one has been baptised in the Holy Spirit like worship, prayer, love, patience and so forth. The gifts of the Holy Spirit are practised by African Pentecostals including the gift of speaking in tongues. African Pentecostals should not put an emphasis on the gift, but on the fruit of the Holy Spirit. The believer should bear the fruit of the Holy Spirit like love, joy, peace, forbearance, kindness, goodness, faithfulness, gentleness and self-control. In most of the churches liturgy among African Pentecostals, the worshippers are found praising and singing in tongues.

However, the public cannot understand this language. Therefore, in addressing the congregants and the public, there should be interpretation to test and approve what has been said in the church and to make other understand what is being said to the church. Otherwise, a common language should be used in this regard.

\section{Acknowledgements}

The author would like to thank the Department of Christian Spirituality, Church History and Missiology for the support provided in conducting this research.

\section{Competing interests}

The author declares that he has no competing interests.

\section{Author(s) contributions}

This article is solely written by M.S.K.

\section{Ethical considerations}

This article followed all ethical standards for a research without direct contact with human or animal subjects. 


\section{Funding information}

This study was financially supported by the University of South Africa.

\section{Data availability statement}

Data sharing is not applicable to this article as no new data were created or analysed in this study.

\section{Disclaimer}

The views and opinions expressed in this article are those of the author and do not necessarily reflect the official policy or position of any affiliated agency of the author.

\section{References}

Amanze, J.N. \& Shanduka, T., 2015, 'Glossolalia: Divine speech or man-made language? A psychological analysis of the gift of speaking in tongues in the Pentecostal Churches in Botswana', Studia Historiae Ecclesiasticae 41(1), 3-19. https://doi.org/10.25159/2412-4265/84

Anderson, A., 1991, Moya: The Holy Spirit in an African context, University of South Africa, Pretoria.

Baer, J.R., 2001, 'Redeemed bodies: The functions of divine healing in incipient Pentecostalism', Church History 70(4), 735-771. https://doi.org/10.2307/3654547

Boddy, B.J. \& Lioy, D., 2016, 'The intercession of the Holy Spirit: Revisiting Romans 8:26-27', Conspectus: The Journal of the South African Theological Seminary 21(03), 2-37.

Busenitz, N., 2006, 'The gift of tongues: Comparing the church fathers with contemporary Pentecostalism', The Master's Seminary Journal 1(1), 61-78.

Cartledge, M.J., 2000, 'The nature and function of New Testament Glossolalia', Evangelical Quarterly 72(2), 135-150.
Chebanne, A.M., 2006, 'The language of the Spirit of the Spirit in the language: A preliminary discussion of glossolalia practices in some Botswana Churches', Scriptura: Journal for Contextual Hermeneutics in Southern Africa 92(1), 167-177.

Constitution-AFM of South Africa, 2018, The Apostolic Faith Mission of South Africa, viewed 01 April 2018, from www.afm-ags.org.

Ford, J.M., 1971, 'Toward a Theology of "Speaking in Tongues"', Theological Studies 32(1), 3-29. https://doi.org/10.1177/004056397103200101

Hollenweger, W.J., 1986, 'After twenty years "research on Pentecostalism"', International Review of Mission 75(297), 3-12. https://doi.org/10.1111/j.1758-6631.1986. tb01446.x

Hwata, B., 2005, 'An investigation of different phases of Pentecostal experience in the Apostolic Faith Mission (AFM)', Doctoral dissertation, University of South Africa, Pretoria.

Machingura, F., 2011, 'The significance of glossolalia in the Apostolic Faith Mission, Zimbabwe', Studies in world Christianity 17(1), 12-29. https://doi.org/10.3366/ swc. 2011.0003

Mashau, T.D., 2013, 'Ministering effectively in the context of Pentecostalism in Africa: A reformed missional reflection', In die Skriflig 47(1), 10-17. https://doi. org/10.4102/ids.v47i1.84

Musoni, P., 2014, 'Glossolalia a theological position in Pentecostal Christianity: A case study of Zimbabwe Assemblies of God Africa Forward in Faith (ZAOGA FIF) spirituality', International Journal of Innovative Research and Development 3(6), 134-140.

Quayesi-Amakye, J., 2016, 'A yeast in the flour: Pentecostalism as the African realisation of the gospel', Studia Historiae Ecclesiasticae 42(3), 71-84. https://doi. org/10.25159/2412-4265/1591

Shumway, C.W., 1919, 'A critical history of glossolalia', Doctoral dissertation, Boston University, Boston, MA.

Stephenson, C.A., 2009, 'Pentecostal theology according to the theologians: An introduction to the theological methods of Pentecostal systematic theologians', Dissertations, Marquette University.

Yarnell, M.B., 2006, Speaking of 'tongues', what does the Bible Teach?, Center for Theological Research, South-western Baptist Theological Seminary, Fortworth, TX.

Yong, A., 2007, 'Pentecostals and the theological academy', Theology Today 64(2), 244-250. https://doi.org/10.1177/004057360706400209

Zerhusen, B., 1997, 'The problem tongues in 1 Cor 14: A re-examination', Biblical Theology Bulletin 27(4), 139-152. https://doi.org/10.1177/014610799702700403 